\title{
SPIRITUALITY IN THE PHILOSOPHICAL THOUGHT OF SEYYED HOSSEIN NASR
}

\author{
Fadhilah Khunaini \\ Institut Ilmu Keislaman Annuqayah Sumenep \\ Email: fadhilah.mr@gmail.com
}

\begin{abstract}
Spirituality for Seyyed Hossen Nast is an inner reality that becomes a religious central in Islam. It is the esoteric dimension hidden in the reality of exoteric Islam. That view on spirituality brings Nasr to the philosophical thought that cannot be separated from religious metaphysical doctrine. Nasr argues that philosophy is more than just a ratio but also the activity of intellect that can reach the meta-cosmic nature to find the essence of truth namely the universal and eternal truth that lies behind the physical and relative truth. The philosophical efforts to find this truth are a combination of the optimizing potential of reason and intellectual intuition. Nasr refers to bikmah or wisdom as a kind of philosophy that combines logic and intellectual intuition. That philosophical view brings Nasr on a dualistic view of nature which not only has a cosmic dimension as such but also has a meta-cosmic dimension. This dualistic view is his fundamental reason in formulating the concept of metaphysical cosmology as a solution to the crisis of modern science that has caused a variety of ecological damage due to the secular vision.
\end{abstract}

Keywords: Seyyed Hossein Nasr, spirituality, philosophy, thought, bikmah, modern science, cosmology

DOI: http://dx.doi.org/10.20414/ujis.v20i2.812 


\section{Introduction}

WHEN I read Seyyed Hossein Nasr in Knowledge and Sacred ${ }^{1}$, I noted the opinion of the duality of reality that based on spirituality discourse. Nasr also sees the importance of spirituality in the completion of the multidimensional crisis suffered by modern civilization. The crisis originated from the Western scholars' underlying assumption that philosophy is essentially a fundamental truth obtained through the activity of reason and rational explanation. Then philosophy comes as a matter of rationality, logic, and language alone. According to Nasr, the structure of human knowledge can be traced as follow. First, metaphysics, the knowledge that explains about the ultimate reality or the absolute reality which is the source, the center and origin of all reality. Metaphysics should be the most basic knowledge because all of the reality can be understood through it as a whole. Second, cosmology as a fundamental view of reality cosmic, cosmology could be a prelude to the understanding of the absolute reality. Because cosmology is the one -in the traditional sense - that explains the natural order as the reality which has a hierarchy and as a theophany or manifestation of absolute reality that it also has a pure quality. ${ }^{2}$ This concept of reality motivated me to go further in elaborating the foundation of Nasr's philosophical thought in this essay.

Therefore, to see more clearly how spirituality becomes the basis in Nasr's philosophical thought, this paper addresses these issues: How Spirituality becomes the core of Nasr's Thought? How far the extent to which wisdom or hikmah becomes the philosophical foundation in Nasr's thought? Does it include in his thoughts on metaphysics as the basis of Islamic philosophy? What is the concept of Metaphysical Cosmology? And what is the contextualization of Nasr's thought? The general purpose of this paper is to perceive the root of spirituality in Seyyed Hossein Nasr's philosophical thought.

1Seyyed Hossein Nasr, Knowledge and Sacred (Edinburgh: Edinburgh University Press, 1981).

2Seyyed Hossein Nasr, The Need for Sacred Science (London: Curzon Press, 1993), 99. 


\section{A Brief Biography of Seyyed Hossein Nasr}

Seyyed Hossein Nasr is a professor of Islamic studies at George Washington University, Washington D.C., a leading scientist in the field of Islamic studies, religious studies and comparative religions, an expert in science philosophy and history. He is the author of 40 books and over 400 articles. $^{3}$

Nasr was born in Tehran on 7 April 1933 of a respectable and educated family. His father Seyyed Valiallah is a scholar, physician, educator and literary scholars. He had been an education minister during the rule of Reza Pahlevi. ${ }^{4}$ Nasr's formal education was pursued in Tehran and Qum which used Persian appropriate curriculum. Here, Nasr received traditional sciences education (philosophy, kaläm, Sufism and Islamic jurisprudence). ${ }^{5}$ It all takes place in the first 12 years of life; these conditions have a significant influence on the building and development of intellectuality of Nasr. ${ }^{6}$ At this early age (12), Nasr went to America to study. He entered in the Paddie School, Hightstown, New Jersey, where he graduated as the valedictorian of the class in $1950^{7}$. After high school, he began studies at the Massachusetts Institute of Technology (MIT) where he majored in mathematics and physics. Nasr's personal search for meaning guided his choices of study in the areas of natural sciences, mathematics, and cosmology. He completed his studies to the M.I.T. with a special pass. While in M.I.T, he was

${ }^{3}$ Mehdi and Zailan Moris Aminrazavi, The Complete Bibliography of The Works of Seyyed Hossein Nasr From 1958-1993 (Kuala Lumpur: Islamic Academic of Science of Malaysia, 1994), xxxv.

${ }^{4}$ William C. Chittick, "Preface," in The Complete Bibliography of the Works of Seyyed Hossien Nasr from 1958 trough April 1993, ed. Mehdi Amin Razavi and Zailan Morris (Kuala Lumpur: Islamic Academy of Science Of Malaysia, 1994), xiii.

5Jane I. Smith, "Seyyed Hossein Nasr," The Oxford Encyclopedia of the Modern Islamic World: (New York: Oxford University Press, 1995), 230.

'Page Matthew Brooks, "A Comparison of Reactions to Postmodernity and Its influence on Theological Method in the Works of Alister McGrath and Seyyed Hossein Nasr" (Dissertation, New Orleans Baptist Theological Seminary, 2008), 11.

7 Ibid. 
able to study under the great philosopher and historian of science Giorgio di Santillano.

Di Santillano who introduces the works of Rene Guenon, a perennial philosopher, is the most important traditionalist figure. Nasr also had the opportunity to explore the library of Coomaraswami, so that he can know more about the thought of traditional philosophers throughout the world such as Frithjof Schuon, Titus Burckhardt, Marco Pallis and Martin Lings. All of them have significant influence to the intellect and spirituality of Nasr. Nasr concluded that, indeed, there is the ultimate truth that can only be accomplished by the intellect that gets emitted from divine revelation. Schuon's works that focus on the theory and practice of spiritual discipline became an important part of the thought and spiritual life of Nasr after that. ${ }^{8}$

After graduating from M.I.T. (1954), Nasr entered at Harvard University with majoring in geological and geophysical and got his M.Sc. (1956). Then he pursued a doctoral level with a specialization in the history of science.

In 1958, at twenty-four-year of age, Nasr completed his doctorate at Harvard with a thesis entitled Conception of Nature in Islamic Thought and Method Used for Its Study by the Ikhwain al-Safä, al-Bìnini and Ibn Sinā, which has later published under the title Introduction to Islamic Cosmological Doctrines.

\section{Spirituality as the Core of Nasr Thought}

The discourse of spirituality is central to the structure of Nasr's thought. In many books and articles on various issues, Nasr always carries the flag of spirituality discourse or also known as Sufism. Especially in Islamic discourse, Razavi gives elaboration as follow: ${ }^{9}$

"It is fair to state that no single issue has been treated more extensively

by Nasr than the mystical dimension of Islam, Sufism. Nasr's passionate writings embrace this aspect of Islam at every available

8Ibid., 12.

${ }^{9}$ Mehdi Aminrazavi, "The Intellectual Contributions of Seyyed Hossen Nasr," in The Complete Bibliography of the Works of Seyyed Hossien Nasr from 1958 trough April 1993, ed. Mehdi Aminrazavi and Zailan Morris (Kuala Lumpur: Islamic Academy of Science Of Malaysia, 1994), xxi. 
opportunity. One can easily see the presence of Sufism in various works of his, be it art and science or philosophy and theology. Sufism for Nasr is not just an aspect of Islam but is the heart of it which provides the structure within which another aspect of Islam can be analyzed."

He is classified as a passionate person when talking about spirituality. Perhaps, no one of the prominent figures that equalizes his confidence and enthusiasm in presenting spirituality in wider perspectives and on a variety of topics.

However, the abundance and diversity of works in the theme of Nasr will not make people classify Nasr in the typology of certain thoughts. For this purpose, it is necessary to determine a central point which could become a major icon in understanding the constellation of his thought in general. Here is where the spirituality becomes a keyword because it has become a breath for the whole thought of Nasr. That is to say; spirituality is not only one of the themes and parts of his thought but also become the paradigm -in Kuhnian's term n's term $n$ the typology of certain thoughts. For this purpose, it istual paradigm is seen especially in the alternative solutions for various problems of modern civilization. It is also observed in numerous studies on the history and ideas that are theoretical. Nasr often criticizes and provides solutions to various studies which were considered deviant. For example, the study of the history of religion and philosophy according to Nasr is too historical and neglect the spiritual aspect.

The root of the religious paradigm can be traced to Nasr's concept of reality which bases on the perennial philosophy. Perennial philosophy --which is in line with many Neo-Platonic theories --describes a portrait of reality in a whole as a circle. Typically a circle, it has a center point (axis) and the edge of the circle line (rim). Center and edge connected by spokes. In this context, the physical reality is the edge of the circle, while the core of reality (absolute reality) is something that is non-physical behind the physical reality. The view of the duality of reality once again confirms that non-physical reality is the absolute 
reality that is often misunderstood by modern society. Absolute reality which is also called the principle by Nasr described as: ${ }^{10}$

"The principle is a reality in contrast to all that appear as real but which is not reality in the ultimate sense. The principle is the absolute compared to which all is relative. It is infinite while all else is finite. The principle is one and unique while manifestation is multiplicative. It is the Supreme substance compared to which all else is the accident. It is the Essence to which all things are juxtaposed as form. It is at one beyond being and being while the order of multiplicity comprised of existence. It alone is while all else becomes, for it alone is eternal in the ultimate sense while all that is externalized partakes of change. It is the Origin but also the End, the Alpha, and Omega. It is Emptiness if the world is envisaged as fullness and Fullness if the relative is perceived as in the light of its ontological poverty and essential nothingness."

Then to achieve the Principle (absolute reality) must use intellect (Latin: intelectus, Greek Nous) that can lift the veil of physical reality. ${ }^{11}$ While the ratio and sense can only be operated in the physical reality that relies on it and they will never reach the core of reality as the actual reality. This theory is used as the core framework of spiritual paradigm in his thinking about various issues and themes.

\section{The Philosophical Tradition of Wisdom}

Before discussing the extent to which wisdom or bikmah becomes the philosophical foundation in Nasr or in the physical reality that relies on it and they will never reach the core of reality as the actual reality. This theory is used as the core framework of this study.

Wisdom is a school of thought in Islamic philosophy that share a belief in mysticism in the use of reason as the most reliable faculty $\mathrm{n}$ mysticism in the use of reason as the most reliable faculty of reality as the actual reality. This theory is used as the core truth should be used and verified through the formulation of discursive demonstration. In short, wisdom is a blend of rational thought and gnostic intuition. ${ }^{12}$ This

${ }^{10} \mathrm{Nasr}$, Knowledge and Sacred, 134.

${ }^{11}$ Seyyed Hossein Nasr, Islam and The Plight of Modern Man (London: Longmans, 1976), 47.

${ }^{12}$ Seyyed Hossein Nasr, "The School of Isfahan," in A History of Muslim 
philosophical school can also be called the transcendent theosophy (Al-Hikmah al-Muta'äliyah). The central figure is Mulla Șadrā13

Belatedly recognized and understood, is now widely accepted that wisdom is a coherent philosophical system, although combining the various school of previous philosophers. According to Murtaḍa Muṭahharī, the significance of Șadrā is not only the fact that he examines the entire legacy of Islamic thought and combines all the current of important thoughts, but also the fact that he produced a sound synthesis of all the currents. This synthesis is not generated necessarily by a superficial "reconciliation" and "compromise," but by a philosophical principle. ${ }^{14}$

Mulla Sadrā is often referred as the founder of the third major school of thought. The first major school of thought is Peripatetic school which the greatest exponent in the Islamic world is Ibn SSin. The other was illuminative school (al-Hikmah al-Ishraqiyah al-Hikmah al-Khälidah) built by Suhrawardi alMaqtūl. ${ }^{15}$ Mulla Ṣadrā also adopted certain principles from each of the schools, such as hylomorphism from peripatetic, gradation of existence and divine archetypes from the illumination school. Even he adopted a particular principle of Sufi teaching of Ibn Sina.

Harmony and regularity substance of the world have not previously appeared as the principle of several schools of wisdom, and never built systematically in logical language by wisdom experts before Mulla Șadrā. Therefore, Mulla Șadrā

Philosophy, ed. M.M. Syarif (Weisbaden: O. Harrossowitz, 1996), 904.

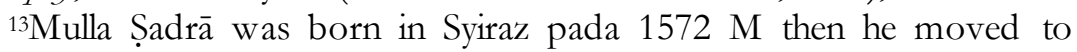
Isfahan - an important central education city at the era. There, Mulla Șadrā learned to Abu Amir Al-Qasim Findereski (d. 1640), then he comes back to Syiraz to be a lecturer in a university in the city. Purportedly, Mulla Șadrā made a pilgrimage to Mecca on foot for seven times, and he passed away in Basyrah on the way from the seventh pilgrimage at 1641. See, Majid Fakhry, Sejarah Filsafat Islam: Sebuah Peta Kronologis (Bandung: Mizan, 2002), 12.

${ }^{14}$ Murtaḍ̄a Muțahharī, Filsafat Hikmah: Pengantar Pemikiran Shadra (Bandung: Mizan, 2002), 68-9.

${ }^{15}$ Ṣihāb al-Dīn al-Suhraw ardī was born in Aleppo, Syria at $1154 \mathrm{M}$, and dead at 1911 M. Fakhry, Sejarah Filsafat, 129. 
appropriately referred to as the founder of the original wisdom and relatively new in the realm of Muslim philosophy that his concept of wisdom called al-hikmah al-muta'aliyah is different with al-hikmah al-mashabl-mah or peripatetic philosophy as well as al-hikmah al-Ishraqiyah or Illusionist theosophy. ${ }^{16}$

\section{Hikmah as the Foundation of Nasr's Philosophical Thought}

According to Nasr, all this time Islamic philosophy is presented not as a whole, because it is done by Western scholars that confine their underlying assumption that philosophy is essentially a fundamental truth obtained only through the activity of reason and rational explanation. Philosophy sometimes also used to analyze and examine the empirical data obtained through the sense as in the British empiricism. The philosophy here is only used for practical purpose. ${ }^{17}$ Consequently, modern philosophy has now been hit by the ontological crisis, because apart from the metaphysical doctrines of religion.

This view also permeates Muslim scholars whom influenced by the west philosophical thought, which is Nasr often referred to as a modernist Muslim. The activity other than the ratio that was also used by the philosophers was not revealed clearly that why Islamic philosophy comes as the Western philosophy which is empty from the metaphysical doctrines of religion. ${ }^{18}$

Through his comparative method, Nasr wants conformity with philosophy as it understood in the West. According to Nasr, the East sees philosophy as the "wisdom," while the West sees philosophy in "technical" terms. So, says Nasr, modes of Western thought cannot be termed as a "Philo-sophia" because they do not love the wisdom. On the contrary, their modes of

${ }^{16}$ Seyyed Hossein Nasr, "Theology, Philosophy, and Spirituality," in Islamic Spirituality Manifestation, Volume 20 of World Spirituality: An Encyclopedic History of the Religious Quest, ed. Nasr (New York: Crossroad, 1980), 443.

${ }^{17} \mathrm{Nasr}$, Islam and The Plight, 46.

18Seyyed Hossein Nasr, Islamic Life and Thought (London: George Allen \& Unwin, 1981), 147. 
thought should be referred to as "miso-Sophia" or "the hatred of wisdom" because of their hatred of the wisdom ${ }^{19}$

Viewing a sharp distinction between East and West in looking at the issue, Nasr tried to give way out to return to the original understanding. According to Nasr, in the Islamic world tradition, philosophy is an integral part of the intellectual activities and spiritual intuition in the strict sense of the thought. Philosophy is a doctrinal part of a comprehensive spiritual path which is accompanied by a realization method and cannot be separated from complete revelation or tradition that has created the spiritual path. On other word Nasr said:

"No philosophy which ignores both revelation and intellectual intuition and thus divorces itself from the twin sources of transcendent knowledge can hope to be anything but disrupting and dissolving influence in Islamic society"20

According to Nasr, the needs of human existential cannot be answered only by analytical philosophy but should be with a combination of contemplation and action, or between rational senses with intellectual intuition (in its original sense). Nasr believes that the authentic philosophy is nothing other than "theosophy" (wisdom or bikmah). He stressed that only with the synthesis of reason and intellectual can deliver someone on the beach of absolute reality. Hikmah in traditional Islamic understanding is the essence of the divine teaching that has been passed down to the prophet in the context of various times and places. $^{21}$

According to Nasr, philosophy in the highest level means Philosophia Perrenis (eternal wisdom), or in Islam, it is known as Hikmah Ladunniyah (divine wisdom)22, namely knowledge about the nature of the wisdom gained directly based on the understanding of the truth. Nasr added, in traditional Islamic perspective, philosophy is a Scientia sacra, activities as it relates to direct knowledge of divinity. ${ }^{23}$

19Ibid., 47.

20Ibid., 150.

${ }^{21}$ Aminrazavi, "The Intellectual," xx.

${ }^{22} \mathrm{Nasr}$, Islam and The Plight, 46.

23Ibid., 47. 
Nasr sees that Islamic philosophy is not merely a bridge of philosophical legacy of Greco-Alexandria until it comes into the hands of the West. In addition to inheriting and adoption, more from that Islam has its authentic philosophy. Islamic philosophical model called by Nasr as "prophetic philosophy. ${ }^{24}$ This issue should be emphasized because it concerns the very principle view. Prophetic philosophy intended to describe Islamic philosophy that worked in the domain that was dominated by the presence of a revealed book. The book is not only as the source of religion law and ethics but also as the source of knowledge and means of access to the truth. ${ }^{25}$ Prophetic philosophy does not only depart from nature or the obvious reality but from al-Qur'an and al-Hadith in the esoteric and exoteric meaning. Both have significant meaning and being the inspiration for the birth of an original philosophical thought. This philosophy is not only built through the efforts of rational and logical (with the ratio/al-aql al-naz̧ari) but also through the intuitive efforts (with the intellect/al-'aql al-fa'ä) to penetrate the transcendence world so as to achieve lect/meaning al-haqiqab). ${ }^{26}$ Both things are commonly undertaken by Muslim philosophers. Mulla Șadrā as one example, after completing his formal education, he lived in an ascetic way near Qum for several years. ${ }^{27}$

Therefore, in the tradition of Islamic philosophy, there are two types of knowledge: al-ilm al-ḩusüli (with the ratio) and al'ilm al-budīì (with the intellect). ${ }^{28}$

${ }^{24}$ This term is used firstly by Henry Corbin (philosophie prophetique). See Nasr, "The Qur'an and Hadith as Source and Inspiration of Islamic Philosophy," in History of Islamic Philosophy, ed. Seyyed Hossein and Oliver Leaman Nasr (New York: Routledge, 1996), 28.

25Nasr, "Theology," 442.

26Nasr, "The Qur'an," 29.

${ }_{27}$ M. M. Syarif, A History of Muslim Philosophy, vol. 1 (Wiesbaden: Otto Harrassowitz, 1996), 935. , 935. In some classic school of Islam, the student pray at first before they study algebra, Khayyam or Risalat al-Kimiya' of Jabir bin Hayyan, as the method of intellect grinding (within the heart) beside ratio (within the mind). Seyyed Hossein Nasr, Islam and Contemporary Society (London: Logman Group, 1982), 179.

${ }^{28} \mathrm{Al}-\mathrm{Ghazali}$ named it Tlm al-Mu'ämalah (by ratio) and Tlm al-Mukāshafah 
Teaching philosophy to Muslim students, according to Nasr, should be reached by some stages as follows: First, giving the Islamic definition and understanding of the meaning of Islamic philosophy. Second, the student must firstly be equipped with the strong fundamental of Islamic philosophy and other disciplines related to it, such as theology, Sufism, and the shari'a. Third, the student is invited to examine the intellectual tradition of Islam as a whole thoroughly. Fourth, the new student is introduced to the thought of the Western philosophers, both classic like Plato, Plotinus, and Aristoteles; Medieval philosophers such as St. Bonaventure, St. Thomas Aquinas; as well as modern Western philosophers such as Immanuel Kant, Rene Descartes, and Hegel. ${ }^{29}$

While in teaching philosophy, Nasr uses caution approach which emphasizes on the needs and consciousness as philosophy should be taught. Relating to the teaching of philosophy, Nasr said: "Islamic philosophy should be made central, and another school of philosophy thought about it. ${ }^{30}$

Nevertheless, Nasr seemed less enthusiastic_- not to say not at all-in the teaching of modern Western philosophy. Beca use for Nasr, since the temporal character, atheistic and secularis tic which is becoming mainstream in Western thought, it means th at the view model is really in contrast to the intellectual life of Isl am, which every thinking development orient on God's revelatio n. ${ }^{31}$

\section{From Ontology to the Metaphysical Cosmology}

In the hands of the Greeks, the understanding of the nature undertaken in the more radical way and philosophical enters the

(by intuition). See Abū Hāmid Muhammad ibn Muhammad al-Ghazālē, Ibyāa 'Ulüm al-Dìn, vol. IV (Dār al-Fikr: n.d.)., Bab al-Fiker. The term buduri and busuli are adopted from Suhrawardī al-Maqtūl 's classification. See Nasr, "Mulla Șadrā: His Teaching," in Nasr and Oliver Leaman. History, 645. In the same meaning, Mulla Ṣadrā -one of Nasr's idol - divided the knowledge to al-Tlm al-suwari (through formal instruction) and al-Tlm al-Ladunni (through intellectual intuition). See Syarif, A History of Muslim, 398.

${ }^{29}$ Nasr, Traditional Islam, 206.

${ }^{30} \mathrm{Nasr}$, Islamic Life, 149.

${ }^{31}$ Mehdi Aminrazavi, The Intellectual Contribution, xxi 
original territory of the philosophical and metaphysical. The early philosophers such as Thales (624-547 BC), Anaximander (610-547 BC) and Anaximenes (585-528 BC) were the natural philosophers. They even called hylicists ("naturalist" or "materialist") for making the nature as the foundation of their philosophy and refused spiritual and religious factors. ${ }^{32}$

With a background in critical thinking skills, the philosophers questioned various popular myths in the society. Since that time the shifting necessary knowledge occurred from the myth to the scientific understanding. Lately, in the new modern era, human understanding is experiencing a rapid development in science and technology, so that since the second period of the twentieth century, the development of human knowledge assessed exceeds its growth since the beginning of history. As well as the philosophy of nature that known as cosmology, it is not just being philosophical knowledge but evolved into the science. ${ }^{33}$

Lately, the global society affected by a multidimensional crisis, from the economic crisis into a crisis of moral and cultural. Everything stems from two major crises: the crisis of humanity and the environment. The two crises are the impact of "the crisis of perception" which bases on modern science with the Cartesian-Newtonian Mechanistic Paradigm. ${ }^{34}$ A paradigm which has penetrated in all scientific disciplines and the thought

${ }^{32}$ Hylicist is originated to bule (Greek language) that means; matter. See Louis P. Pojman, Philosophical Traditions, a Text with Readings (New York: Wadsworth Publishing Company, 1998), 31-2.

${ }^{33}$ Christian Wolff introduced the term of cosmology (1771) as the part of particular metaphysic. According to Wolff, metaphysic divides to two forms: (1) general metaphysic, that is the ontology, and (2) special metaphysic, that is cosmology (nature), theology (God), and psychology (human). In its development, cosmology is divided into two forms: metaphysic cosmology (philosophy) and empiric cosmology (scientific). See Piroos Fatoorachi, "The Problem of Beginning, Modern Cosmology, and Transcendent Hikmah," Islamic Studies Journal 39, no. 4 (2000): 634.

${ }^{34}$ According to Capra, the modern science based on three pillars: Descartes' philosophy, the Newton's theory of mathematic and F. Bacon's scientific method. See Fritjof Capra, Titik Balik Peradaban, trans. M. Thoyibi (Yogyakarta: Bentang, 1999), 31. 
systems of almost all of people in the world, that paradigm is proved not fully explain the reality as a whole. Therefore, efforts to resolve the problem faced always fail or lead to new challenges.

In this context, Nasr sees that modern science has led to a multidimensional crisis. Science has become a "religion" (scientism), and the fundamental weakness is the perspective of nature. As a scientist, Nasr is well aware that science moves over the particular lines of paradigm. Therefore, in his critique of modern science, Nasr pointed to the paradigm as the root of the problem, which is a worldview toward reality. With the empiric Cartesian-Newtonian paradigm, modern science viewed the material as the core reality that moves on the laws of mechanics. ${ }^{35}$

This worldview leads to the reality in one dimension, the material dimension, no other side, which is known as "materialism." For Nasr, this is the roots of the problem. Based on materialism, modern men develop the science in the form of technology to exploit nature heavily. Because the standard of life is material, so it is believed that the material can cause happiness and give an existential meaning of life.

Based on the thesis on the root of the problem formulated above, Nasr wanted to offer a solution through a shifting paradigm, which became the fulcrum of modern science. For a variety of existing solutions to tackle the world, the crisis is not considered essential, dwell only on the surface and touches the areas that are not principle. It also includes what is conducted by religious leaders in the West through the "Environmental Theology or Eco-theology" formulation they offer. One of the fundamental weaknesses is not to reconstruct its secular worldview of cosmic reality. ${ }^{36}$

\section{Cosmos as Theophany}

As adherents of traditionalism, ${ }^{37} \mathrm{Nasr}$ sees cosmic reality not as a single picture but as one aspect of reality as a whole. Even

\footnotetext{
35Nasr, Religion and The Order, 13 and 273.

36Ibid. 5.

${ }^{37}$ About the meaning of tradition, see Nasr, Knowledge and Sacred, 65-86.
} 
cosmic reality is the part that is not the principle. The cosmic reality in the material form is accidents of a substance that is in the realm of meta-comic. ${ }^{38}$

The cosmic reality is the universe that is worldly material. It is considered as one of the accidents of absolute reality, namely The Real---God in religious language-- that is in the fact of meta-comic. Accidentals quality is owned by the cosmic reality due to its existence as the theophany of the Real. The Real that is absolute and the basis of all life manifests itself in the cosmic reality. ${ }^{39}$ Obviously, the cosmic reality is not a material reality a sich that such independent from another reality.

With its existence as a theophany of The Real, cosmic rea lity becomes a symbol of a spiritual truth of all that are in the rea $\mathrm{lm}$ of meta-comic. All things in the universe is a symbol that can be icons for contemplation matter. ${ }^{40}$ Because by being theopha ny, the cosmic reality means "a stage" where the names and attri butes of the divine scriptures (Divine Names and Qualities)are s howed. In another language, a cosmic reality is a large book whi ch contains the mind of God. Mountain, rock, sea, tree, etc. mai nly includes the gnostic message of God. ${ }^{41}$ In Islamic themes, th e entire universe is a sign (ayat) of Allah. Because of its contents, the universe is also called "the cosmos Qur'an" (al-Qur'an al-take wini), while the Qur'an that contains verses in the form of verbal language is called "the written Qur'an" (al-Qur'an al-tadwini). ${ }^{42}$

As a "sign," thus, the cosmic reality is a revelation in the sense of origins or comes from God; it is an objective reality that exists to be read by the human that can transcend itself towards absolute Reality. With its position, that cosmic reality is also called "objective revelation" or "universal revelation"(al-

38Ibid., 132; The Encounter, 31; Religion and, 158. About metaphysic in this traditional sense, Nasr referred to Schuon. See F. Schuon, "Oriental Metaphysics,"40-56.

39Ibid., 191, 241.

40Ibid, $191-192$.

${ }^{41}$ Ibid.

42Ibid. See Nasr, "Islam" in Arvin Sharma (ed.), Our Religions (New York: Harper Collins Publisher, 1995), 462. Islamic Spirituality Foundations, 345; The Need for, 101. 
wabyu al-kulli). This kind of revelation is passive. The active characters are within the human being that is also a revelation because they also come from God even being a perfect mirror of God and carry the image of God (fitrab). Therefore the human is also called subjective revelation or "particular revelation" (al-wabyu al-juz'i). ${ }^{43}$

The effort to reach the Reality through realizing that cosmic reality as theophany and "tunnel" that must be passed to the meta-comic nature presupposes nature as symbols and not merely facts. Everything in the universe is theophany, a reality that means as a sign of the truth behind the looks.

The concept of cosmic reality as a "sign," symbol, theophany, "tunnel" has implications on the idea of creation that is not seen as a process like an artisan to create a product. God as a Supreme Being created through a process of selfmanifestation. Supreme Being manifestation to cosmic reality bol, theophany, "tunnel" has implications on the idea of creation that is not seen as a process li The cosmic reality is the most recent manifestation of an entire hierarchy of divine manifestation. In the description of the hierarchy of reality, Nasr borrowed the concept Ibnu Arabi about five presence of God (al-hadirah al-ilähiyah al-khamsah) or Five Divine Presences. They are (1) bahut, The self of God himself with all the attributes of perfection (the essence of reality). (2) labut, the level of the highest place of the names and attributes of God (quiddity). (3) jabarüt, the level of the "angle" world (spirit). (4) malakeut, the level of the soul and subtle material (animistic). (5) mulk, the level of the physical-material world. Material level is also often called nasut. In this gradation level, a higher level should include the lower. 44

Levels of reality also work in the hierarchical mechanism. Everything that happens in the material nature (natural rough)

${ }^{43}$ According to Schuon, God's revelation is divided into three: scripture (written revelation), the universe (objective revelation), and human's intellect (subjective revelation). Those are an integral that composes the central thesis in Islam that with his fitrah, the God creates and gives knowledge. See F. Schuon, Understanding, 13.

${ }^{44}$ Nasr, Knowledge and Sacred, 199. 
covered by a subtle or psyche nature, which form a natural dynamic reality under the law and the rhythm set by spirit nature. The law is a manifestation of a high level that is attributed nature or quiddity of ultimate Reality. As the reflection of its characteristics, of course, these laws are in line with the Divine Will. And so the natural law in the traditional sense is the Divine Law or the revealed law, namely the laws that come from God trough the intellect as "universal reason" that govern everything that happens in the earthly realm. This law is the object of studies in traditional science to find the essential knowledge in the domain of noumena, penetrating phenomenon reality of modern science. The law of God is a real and objective reality but under that is in the meta-cosmic that requires intellect to access it. 45 Then in the eyes of traditionalists, the law of God is not understood as the "permissive" law by the Will of God in the theologian view as opposed to the natural law which considered fixed consistently and universally by scientists and philosophers. ${ }^{46}$

Laws and rhythms that have been established by God touch all kinds of the creature in the cosmic world without exception. With the provision that nature could not resist the slightest so that the motion of nature is something fixed and universal and be in agreement with law of God which bases on His will. Only humans as anthropomorphic being-who got the gift of the ability to resist such provision. With the ability, the human being can be involved in the Divine Will. With that, the human existence can be understood as the "image of God. ${ }^{47}$

Sanctity of cosmic reality not only at the level of the material but also related to the laws govern its work. Due to the cosmic reality and its laws are two inseparable sides. In the religious language, God rules not only to human but also toward nature. Except nature does not have the freedom of choice to obey or

45Ibid., 194-5.

${ }^{46} \mathrm{About}$ the authority of nature's law and God's law (Sunnah Alläh) is the most popular topic in the debating of Islamic Theologian and Islamic Philosopher in the past. It was like appeared in the polemic of al-Ghazali and Ibn Rushd that was inclined to the theology and philosophy.

${ }^{47}$ Nasr, Knowledge and Sacred, 195. 
oppose it. Nature can only be subject to the rules given. The laws derive from The Real that is "Divine Law." It stems from the Divine Will in manifest itself in the form of cosmic material and its laws. ${ }^{48}$

\section{Cosmic Reality as a Sacred}

Nasr's philosophical view about the cosmic reality is formulated to make it as a new paradigm of science. It is presented to be accepted as a basic knowledge that should be the foundation of all sciences. According to Nasr, modern science has dumped that principle of reality and not recognize it as the truth. This kind of view is a wrong belief in the scientific world and thus being the origin of the poor orientation with its terrible impact. Herein lies the significance of the shifting paradigm in the platonic sense, a shift touches a worldview that comes from the faith in the traditional sense, and entered into a central of the existence and become the foundation and core of all knowledge of reality. ${ }^{49}$

With this paradigm, metaphysical cosmology not only aims to present knowledge. Further, it intends to lead to the direct experience that will have implications for the birth of awareness of the pure quality of cosmic reality. The awareness will bring to a new world view. In world view, purified cosmic reality as the core study of traditional cosmology is the view that: (1) Declaring that nature as the theophany of the Ultimate Reality through the hierarchy of reality. (2) Understanding the existence of vertical causes and sacred sources of determination, that governs it. (3) Feeling the presence of God in every object which follows other qualitative content. And (4) unseen nature as a reality with only material dimension, but also as a living reality, has the aspect of the soul and spirit, as the human, too. ${ }^{50}$

An attitude that seeks harmony with the nature is an important task of human in life. Because in the traditional teaching, the whole thing has a "dependency" to one another. The whole is unity of reality that comes from a single origin.

48Ibid., 132-3.

${ }^{49}$ Nasr, Religion and, 237

${ }^{50}$ Nasr, Islamic Life, 83. 
Then in addition to creating harmony between the content of nature, the man also has a task to create an equilibrium between "earth/worldly" and "celestial/ Heaven. ${ }^{51}$

With the harmony between nature and man rooted in the worldview of the sacredness of the universe, it is expected the rise of wisdom in using the natural potential, so that causes happiness in life. Then knowledge will serve to selftranscendence.

An attitude that seeks harmony between nature and man is missing from current science orientation, which in turn affect to the environmental crisis. Even though Nasr never against the achievements of modern science that have many benefits for human life. It just needs to be equipped with an adequate primary view. That is to say, even if engaged in particular science, a scientist must have the ability to access the reality behind the physical-material world, to obtain a complete view and understanding its sacred quality. This ability will appear with high morality in the application of knowledge through technology or other. Harmony, balance, peace of life will be the more real ideas.

It was evident that Nasr brings religious ideology in the form of spirituality in offering the new paradigm. Razavi called the idea of Nasr as an effort to position science within the framework of religion". ${ }^{2}$ But religion in this context is present as the teaching of metaphysical spiritual about reality, since the rational explanation of Nasr on cosmic reality rooted in religious teachings, especially from sacred sources, which are then exploited further with a form of philosophy."

\section{The Contextualization of Nasr Thought}

\section{Contextualization in Spirituality}

The important thing I derived from Nasr's philosophical thought is his effort to make spirituality or mysticism as a source of knowledge that should be accepted as well as philosophy in general sense. To understand Nasr's ideas we need to be aware

\footnotetext{
51Ibid, 271.

${ }^{52}$ Aminrazavi, The Complete, xxii.
} 
of his distinction between philosophy and metaphysics. By defining metaphysics or Scientia sacra as 'the science of Ultimate Reality,' Nasr aims not only to distinguish it from metaphysics in its conventional sense but also to present it as the only 'discipline' or 'science' through which one can attain Ultimate Reality. According to Nasr, Philosophy relies on reason and sense experience, whereas metaphysics, although drawing upon reason, is based fundamentally on the intellect (mystical vision). Philosophy aims to convince people, while metaphysics seeks to illuminate and sanctify those who are prepared to undergo such transformation. In Nasr's thought, Kant's Critique of Pure Reason would represent philosophy, whereas 'Arabi's Bezel of Wisdom would represent metaphysics. ${ }^{53}$ Nasr hoped to encourage a new appreciation for Islamic tradition, in this case, is mysticism, and philosophy among the intelligentsia.

\section{Hikmah as an Alternative Philosophical Thought}

The dualistic view on nature has consequences in the dualistic epistemological concept, namely the recognition of intuition as a legitimate source of truth in addition to ratio. So the philosophical endeavor in obtaining the truth should be using these two sources simultaneously and in a balanced way. Hikmah or wisdom is a kind of philosophy that combines reason and intellectual intuition. According to Nasr, hikmah is Islamic authentic philosophy. Islamic philosophical model called by Nasr as "prophetic philosophy. ${ }^{54}$

Nasr has written extensively on how Muslims can embrace contemporary ideas yet hold to traditional beliefs and doctrines. Nasr promotes bikmah because he believes that the modernistic trends of the world make human rely more upon "scientific knowledge" than upon "sacred knowledge." By scientific knowledge, Nasr means knowledge gained by empirical or rational means. For example, the natural and social sciences would be classified as scientific knowledge. Sacred knowledge is knowledge of God as

${ }^{53}$ Adnan Aslan, Religious Pluralism in Christian and Islamic Philosophy: The Thought of John Hick and Seyyed Hossein Nasr (London and New York: Routledge Curzon, 2004), xiii.

${ }^{54}$ Nasr, "The Qur'an," 28. 
revealed and transmitted through the traditional doctrines and teaching of religion. Empirical and rational faculties alone cannot ascertain divine knowledge, but only when it is revealed through sacred scriptures and Gnostics-like revelations to individuals.

\section{Conclusion}

What we can learn from Seyyed Hosen Nasr's philosophical thought is that philosophy is not simply rational work that ends in itself. Rather, it entails spirituality that is able to search the central and universal truth behind reality. To him, nature has two dimensions, namely esoteric and exoteric realms. These element can be grasped by hikmah that integrate logic and intellectual intuition.

Nasr's ontological view of nature and epistemological thought should have an impact on the axiological values toward nature that more responsible, more respectful and more environmentally friendly. Further, based views of the traditional cosmology will affect to new attitudes and behavior towards nature. The point of view is that responsibs for selftranscendence and attain wisdom, not for exploitation. ${ }^{55}$

\section{References}

al-Ghazālī, Abū Hāanid Muḥammad ibn Muḥammad. Ibyā' 'Ulūm al-Dìn. Vol. IV. Dār al-Fikr, n.d.

Aminrazavi, Mehdi. "The Intellectual Contributions of Seyyed Hossen Nasr." In The Complete Bibliography of the Works of Seyyed Hossien Nasr from 1958 trough April 1993, edited by Mehdi Aminrazavi and Zailan Morris. Kuala Lumpur: Islamic Academy of Science Of Malaysia, 1994. Aminrazavi, Mehdi and Zailan Moris. The Complete Bibliography of The Works of Seyyed Hossein Nasr From 1958-1993. Kuala

${ }^{55} \mathrm{Nasr}$, Knowledge and Sacred, 4. By this principles, the orientation is getting "harmony" with nature as "the partner of theophany's, the meant is the Top of Reality manifest itself in the cosmic reality as macro cosmos and human as microcosmos. So that, the human is the miniature of cosmic reality. This also carries to a conviction which said that human is the center of everything. See Nasr, Religion and, 277. 
Lumpur: Islamic Academic of Science of Malaysia, 1994. Aslan, Adnan. Religious Pluralism in Christian and Islamic Philosophy: The Thought of John Hick and Seyyed Hossein Nasr. London and New York: Routledge Curzon, 2004.

Brooks, Page Matthew. "A Comparison of Reactions to Postmodernity and Its influence on Theological Method in the Works of Alister McGrath and Seyyed Hossein Nasr." Dissertation, New Orleans Baptist Theological Seminary, 2008.

Capra, Fritjof. Titik Balik Peradaban. Translated by M. Thoyibi. Yogyakarta: Bentang, 1999.

Chittick, William C. "Preface." In The Complete Bibliography of the Works of Seyyed Hossien Nasr from 1958 trough April 1993, edited by Mehdi Amin Razavi and Zailan Morris. Kuala Lumpur: Islamic Academy of Science Of Malaysia, 1994.

Fakhry, Majid. Sejarah Filsafat Islam: Sebuah Peta Kronologis. Bandung: Mizan, 2002.

Fatoorachi, Piroos. "The Problem of Beginning, Modern Cosmology, and Transcendent Hikmah." Islamic Studies Journal 39, no. 4 (2000).

Muțahharī, Murtaḍā. Filsafat Hikmah: Pengantar Pemikiran Shadra. Bandung: Mizan, 2002.

Nasr. "The Qur'an and Hadith as Source and Inspiration of Islamic Philosophy." In History of Islamic Philosophy, edited by Seyyed Hossein and Oliver Leaman Nasr. New York: Routledge, 1996.

Nasr, Seyyed Hossein. Islam and The Plight of Modern Man. London: Longmans, 1976.

------. "Theology, Philosophy, and Spirituality." In Islamic Spirituality Manifestation, Volume 20 of World Spirituality: An Encyclopedic History of the Religious Quest, edited by Nasr. New York: Crossroad, 1980.

------. Islamic Life and Thought. London: George Allen \& Unwin, 1981.

------. Knowledge and Sacred. Edinburgh: Edinburgh University Press, 1981.

-----. Islam and Contemporary Society. London: Logman Group, 1982. 
------. The Need for Sacred Science. London: Curzon Press, 1993.

-----. "Islam." In Our Religions, edited by Arvin Sharma. New York: Harper Collins Publisher, 1995.

------. "The School of Isfahan." In A History of Muslim Philosophy, edited by M.M. Syarif. Weisbaden: O. Harrossowitz, 1996.

Pojman, Louis P. Philosophical Traditions, a Text with Readings. New York: Wadsworth Publishing Company, 1998.

Smith, Jane I., "Seyyed Hossein Nasr," The Oxford Encyclopedia of the Modern Islamic World: (New York: Oxford University Press, 1995).

Syarif, M. M. A History of Muslim Philosophy. Vol. 1. Wiesbaden: Otto Harrassowitz, 1996. 